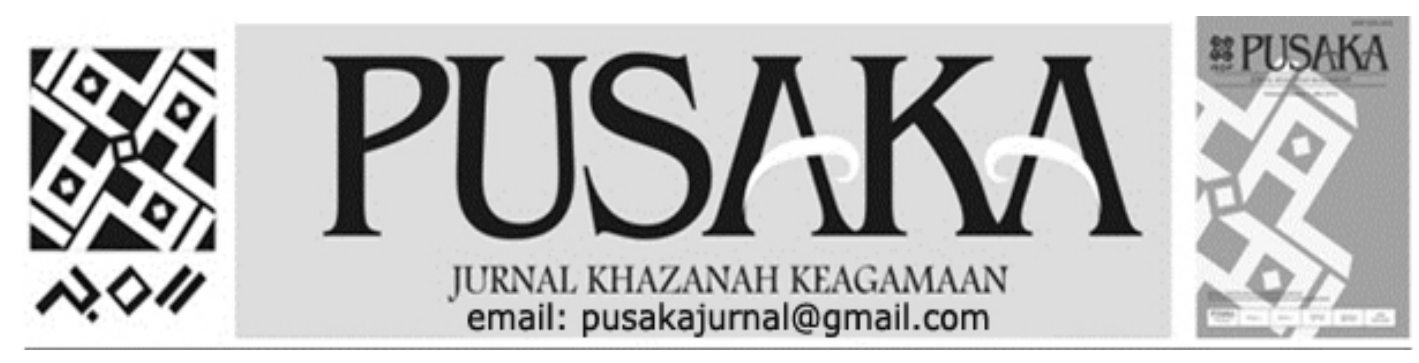

\title{
Sepenggal Warisan Tertulis di Negeri Buton
}

\section{A Piece of Inheritance Written in Buton Land}

\section{Husnul Fahimah Ilyas}

Balai Penelitian dan Pengembangan Agama Makassar

Jl. A.P. Pettarani No.72 Makassar. Telp: 0411-452952

Email: husnul_natalia@yahoo.com

\begin{tabular}{|c|c|}
\hline $\begin{array}{c}\text { Info } \\
\text { Artikel }\end{array}$ & Abstract \\
\hline $\begin{array}{c}\text { Diterima } \\
30 \\
\text { Januari } \\
2017\end{array}$ & $\begin{array}{l}\text { Penelitian ini beranjak dari pemetaan dan sejarah awal manuskrip di Negeri Buton } \\
\text { khususnya pada masa kesultanan Buton. Hal ini sangat penting dikarenakan } \\
\text { manuskrip merupakan saksi sejarah pada masa lampau yang dapat memberikan } \\
\text { informasi yang sangat berharga. Penelitian ini betujuan untuk memperoleh } \\
\text { masukan dalam rangka mengangkat nilai-nilai budaya lokal dan kearifan tradisi } \\
\text { atau kearifan lokal (locl wisdom) dalam rangka merajuk kebudayaan nasional dan } \\
\text { integrasi bangsa. Temuan penelitian ini mengungkapkan sejumlah manuskrip } \\
\text { terselamatkan karena diperlakukan sebagai benda pusaka yang diwariskan secara } \\
\text { turun temurun. Jumlah manuskrip keagamaan yang teridentifikasi, dikoleksi secara } \\
\text { personal, sebanyak } 359 \text { yang tersebar di tiga kecamatan yaitu Kecamatan Murhum } \\
\text { di Kelurahan Wameo, Wajo, Melai, Baadia, Lanto, dan Tarafu. Di Kecamatan } \\
\text { Wolio Kelurahan Batulo, Toba, dan Wangkanapi. Di Kecamatan Kokalu-kuna } \\
\text { Kelurahan Kadolomoko. Manuskrip yang ditemukan berisi tentang Tasawuf, } \\
\text { Khutbah, Ilmu Kabatinan, Silasilah Raja dan Sultan Buton, Arsip Kerajaan dan } \\
\text { Kesultanan, Ilmu Agama Islam, Doa-doa, Hadis, Tauhid, Fiqhi, Hadis, Silsilah, } \\
\text { Syarf al-Anam, Insan Kamil, Tauhid Alquran, serta Kabanti. Kondisi manuskrip } \\
\text { yang ditemukan sekitar 80\% masih utuh dan masih bisa terbaca dan } \\
\text { keberlangsungan penyalinan manuskrip masih dilakukan sampai sekarang. } \\
\text { Kata kunci: Manuskrip, Kesultanan, Buton. }\end{array}$ \\
\hline $\begin{array}{c}\text { Disetujui } \\
18 \\
\text { April } \\
2017\end{array}$ & $\begin{array}{l}\text { This research moved from the mapping and early history of manuscripts in the } \\
\text { country of Buton specialyat the time of the sultanate of Buton. This is very } \\
\text { important because the manuscripts is a historical witness in the past that can } \\
\text { provide valuable information. This study aims to obtain inputs to elevate local } \\
\text { cultural values and traditional wisdom or local wisdom to embrace the national } \\
\text { culture and national integration. The findings of this study reveal many of } \\
\text { manuscripts saved by being treated as genetic inherited heritage. The number of } \\
\text { identified religious documents collected personally, 359 spread in three sub- } \\
\text { districts namely Murhum Sub-district in Wameo, Wajo, Melai, Baadia, Lanto, } \\
\text { Tarafu Sub-districts. In Wolio Subdistrict Batulo, Toba, and Wangkanapi } \\
\text { Subdistrict In Kecamatan Kokalu-kuna Kadolomoko. The manuscripts that were } \\
\text { found contained about Sufism, Khutbah, and Sultan Buton, Royal Archives and } \\
\text { Sultanate, Islamic Science, Prayers, Hadith, Tawheed, Fiqh, Hadith, Lineage, } \\
\text { Syarful Anam, Insan Kamil, Tawheed Alquran, and Kabanti. The manuscript } \\
\text { condition found around 80\% is still intact and still readable. } \\
\text { Keywords: Manuskrip, Sultanate, Buton. }\end{array}$ \\
\hline
\end{tabular}




\section{PENDAHULUAN}

Perjalanan sejarah suku-suku bangsa di Nusantara Indonesia bermula pada abad yang lalu dan mempunyai kontiunitas sampai saat ini, meskipun telah melewati berbagai fase perkembangan dalam irama masing-masing. Fase-fase perkembangan sejarah itu mewariskan peninggalanpeninggalan yang berharga sebagai karya terbaik zamannya. Berbagai macam bentuk peninggalan sejarah yang bertahan sampai saat ini, seperti benda-benda kuno (artefak), tradisi lisan, dan tradisi tulis.

Batu tertulis (prasasti), catatancatatan tertulis atau kronik, dan tradisi tulis lainnya merupakan sumber data terpercaya untuk mengkonstrusikan kembali sejarah suku-suku bangsa itu, sekaligus mengungkap berbagai macam falsafah hidup, modal budaya, dan tatanan kehidupan sebagai jati dirinya. Hanya saja sumber-sumber sejarah berharga ini banyak yang telah rusak, hilang, dan terabaikan oleh pemiliknya, atau berpindah tangan kepihak asing, sehingga yang tersisa dimasyarakat merupakan barang langka.

Persentuhan agama Islam dengan berbagai suku-suku bangsa atau kerajaan-kerajaan di Nusantara sejak dahulu kala memberikan pengaruh besar terhadap perjalanan hidup dan perkembangannya. Berbagai kerajaan-kerajaan Islam mencatat kejayaannya mulai bagian barat Nusantara (Sumatera) seperti Kerajaan Perlak sampai bagian timur Nusantara (Maluku) seperti Kesultanan Ternate.

Sejak abad ke-12, di Indonesia tercatat sejumlah pusat-pusat studi keislaman. Seperti di kerajaankerajaan yang menerima keberadaan ulama untuk mengajarkan mengenai Islam hal tersebut sangat mendukung tumbuhnya pusat-pusat studi keislaman. Tulisan-tulisan mereka tersebar secara meluas. Tulisantulisan mereka inilah yang memiliki nilai dan bobot yang sangat berharga yang menarik minat masyarakat dari berbagai pelosok Nusantara untuk menuntut ilmu dan berguru.

Manuskrip kuno yang bernafaskan Islam itu merupakan saksi sejarah atas kejayaan Islam di Nusantara pada masa lampau, yang masih tersebar di berbagai wilayah Nusantara. Bahkan beberapa manuskrip tersebut telah diinventarisasi bersama-sama oleh lembaga resmi pemerintah, museum, tempat-tempat penyimpanan bendabenda purbakala lainnya, Pepustakaan dan Badan Arsip Nasional, dan beberapa perpustakaan negara luar, namun masih banyak manuskrip tersebut yang belum diinventarisasi dan terdokumentasi yang masih tersebar dan tersimpan di tangan masyarakat atau pemiliknya. Studi mengenai manuskrip ini sangat dibutuhkan sebagai salah satu sumber acuan studi sejarah, studi keislaman dan keindonesiaan, dan studi kependidikan Islam.

Berdasarkan latar belakang permasalahan di atas, maka penting untuk menelisik kembali manuskrip yang masih tersimpan di kalangan masyarakat Buton. Adapun permasalahan dalam penelitian ini adalah bagaimana sejarah manuskrip di Buton? Manuskrip keagamaan apakah yang masih dapat ditemukan di kalangan masyarakat di Sulawesi 
Tenggara?

Bagaimanakah penyimpanan dan pemeliharaan manuskrip keagaman itu oleh pemiliknya?. Penelitian ini betujuan untuk memperoleh masukan dalam rangka mengangkat nilai-nilai budaya lokal dan kearifan tradisi atau kearifan lokal (local wisdom) dalam rangka merajuk kebudayaan nasional dan integrasi bangsa. Tujuan khusus yaitu untuk mendiskripsikan kondisi manuskrip keagamaan yang masih dapat ditemukan dikalangan masyarakat, kemudian diinventarisasi, dipetakan, dan diklasifikasi.

\section{Kajian Pustaka}

Penelitian ini bukanlah penelitian yang pertama dilakukan. Sejumlah lembaga telah melakukan penelitian dan kajian yang sama seperti Perpustakaan Nasional Republik Indonesia telah memiliki koleksi yang termuat publikasi sejak abad ke-16, baik terbitan Indonesia maupun luar negeri, karya bangsa Indonesia dan pengarang asing. Dari koleksi itu ada koleksi khusus yang langkah, yakni manuskrip Nusantara yang jumlahnya cukup besar, mewakili semua kesusastraan daerah di Indonesia. Koleksi manuskrip tersebut ditulis dalam berbagai bahasa dan aksara daerah serta menggunakan berbagai bahan seperti bambu, kulit kayu, lontar, nipah, dan beberapa jenis kertas. Pada umumnya, isi manuskrip mengenai filosofi, kebudayaan, sejarah, cerita rakyat, dan mantra yang merupakan ungkapan pengalaman para pengarangnya pada zamannya yang diwariskan kepada anak, generasi muda penerus bangsa yang wajib dilestarikan (Behrend, 1998: ix).
Adapun koleksi manuskrip Perpustakaan Nasional Indonesia terdiri atas dua kelompok besar, yaitu koleksi manuskrip berupa buku berjilid yang disimpan dalam bebarisan rak besi, diurut sesuai sub koleksi; dan koleksi "non buku" tersimpan dalam peti sesuai urutan nomor petinya. Manuskrip jilidan terbagi atas 17 sub koleksi yang cukup jelas identitas dan sejarahnya, sedangkan naskah peti terbagi 38 subkoleksi.

Buku Katalog Induk Naskahnaskah Nusantara Sulawesi Selatan memuat sebanyak 4049 buah naskah yang telah diinventarisasi dan dimikrofilm. Rol negatif dari microfilm ini tersimpan di Kantor Arsip dan Perpustakaan Daerah Sulawesi Selatan (Paeni, 2003). Pada umumnya, manuskrip yang dimicrofilm diperoleh dari berbagai daerah di Sulawesi Selatan (termasuk Sulawesi Barat sekarang) dan Sulawesi Tengah. Berbagai macam isi dari manuskrip tersebut, seperti masalah budaya, atau dapat dan pemerintahan dan keagamaan. Naskah-naskah keagamaan (bernafaskan Islam) cukup banyak, baik berkaitan dengan tasawuf, fikih, sejarah atau doa. Hanya saja jumlah naskah yang bernafaskan Islam itu sulit ditentukan secara pasti karena banyak naskah memuat berbagai macam di dalamnya termasuk masalah agama (Islam).

Katalog naskah kuno yang bernafaskan Islam di Indonesia, Buku I dan II yang diterbitkan oleh Puslitbang Lektur Keagamaan Badan Litbang dan Diklat Departemen Agama RI memuat hasil-hasil penelitian pernaskahan yang telah dilakukan Puslitbang Lektur 
Kegamaan. Sebagai katalog, yang dikemukakan dalam buku ini terbatas identitas dan anotasi singkat. Identitas naskah memuat: penulis, bahasa, dan huruf yang digunakan, waktu penulisan, jenis naskah, panjang naskah, dan tempat naskah. Pada buku I memuat sebanyak 368 naskah dari 8 provinsi dan pada Buku II sebagai kelanjutan memuat naskah-naskah lainnya sehingga mencapai jumlah seluruhnya 759 naskah (Mulia, 1999).

Buku Naskah Klasik

Keagamaan Nusantara I memuat hasil-hasil penelitian pernaskahan yang dilakukan Puslitbang Lektur Keagamaan yang dilaksanakan sejak tahun 2003. Berbeda dengan buku Katalog yang telah dikemukakan, buku ini merupakan wujud sosialisasi dan publikasi tentang warisan budaya bangsa sehingga lebih banyak mengungkap isi atau pesan yang terkandung dalam naskah-naskah yang ditemukan. Buku ini memuat 7 hasil penelitian pada berbagai daerah, yaitu :1. Kitab Sittin (NTB) 2. Tuhfah al-Rāgibīn, Sirāj alMubtadin, dan Asrār al-Salah (Kalimantan Selatan) 3. Serat Piwulang (Yogyakarta) 4. Al-Sayr fí Mațāib al-Lawāqib, al-Minah alSanaiyah dan Ajaran I'timan (Jawa Barat), 5. Kanz al-Ma'rifah (Kalimantan Selatan), 6. Samarat alMuhimmah, Syair Barudah, dan Syair Hikayat Tengkurak Koriang (Riau), 7. Babad Tanah Jawa (Pesisiran) Jawa Timur.

Buku Direktori Edisi Nusantara memberi informasi tentang naskahnaskah Nusantara yang telah dikerjakan pengedisiannya serta sampai sejauh mana pengedisian dilakukan. Data yang dicatat dalam direktori ini antara lain judul naskah, jumlah naskah yang digarap dengan judul naskah tersebut, bahasa dan aksara yang digunakan dalam naskah itu, tempat ditemukan naskah, waktu penyusunan, dan penulisan teks/karangan yang terdapat dalam naskah, identitas penyusunan, serta penulis naskah. Edisi naskah-naskah yang termuat dalam buku ini adalah Aceh, Bali, Banjar, Batak, Bugis, Gorontalo, Jawa, Melayu, Minangkabau, Sasak, Sunda, dan Wolio (Ekadjati, 2000). Edisi naskahnaskah dari Kawasan Timur Indonesia hanya Bugis 81 edisi, Gorontalo dua edisi, dan Wolio dua edisi.

\section{Metode Penelitian}

Lokasi penelitian dilaksanakan di Kota Bau-Bau (yang merupakan bekas wilayah Kesultanan Buton) Provinsi Sulawesi Tenggara. Penelusuran manuskrip dilakukan pada masyarakat, tokoh agama (lakina atau aparat masjid), dan kolektor. Sebagai salah satu sumber penelusuran manuskrip adalah aparat masjid, pemda yang berkaitan dengan pernaskahan, akademisi, tokoh masyarakat, dan pemilik naskah. Penentuan informan dilakukan denga teknik "bola salju". Penelitian ini bersifat kualitatif, maka pengolahan dan analisis data dilakukan secara kualitatif. Sebagaimana lazimnya pada penelitian kualitatif, pengolahan dan analisis data dalam penelitian ini dilakukan sejak saat pengumpulan data di lapangan. Pengolahan data dilakukan dengan verifikasi, klasifikasi, dan kategorisasi data. Data manuskrip dilakukan analisis filologi terbatas dan kodikologi. 
Berkaitan dengan analisis manuskrip, terdapat kategori data yang disediakan untuk setiap manuskrip yaitu: lokasi tempat manuskrip, nomor manuskrip, pemilik manuskrip, alamat pemilik manuskrip, tempat penyimpanan manuskrip, alamat penyimpanan, penulis manuskrip, tanggal dan tahun penulisan manuskrip, tempat penulisan, penyalin manuskrip, tanggal dan tahun penyalinan manuskrip, tempat penyalinan, judul manuskrip, judul luar, judul dalam, ukuran manuskrip, ukuran teks, jumlah halaman, jumlah baris dalam satu halaman, panjang garis dalam satu halaman, jenis tulisan/huruf, bahasa, bentuk karangan, bahan manuskrip, tinta, watermark, kuras, garis panduan, iluminasi, ilustrasi, sampul manuskrip, jilidan manuskrip, halaman kosong, halaman bergambar, penomoran halaman, keadaan manuskrip (fisik), sejarah manuskrip, isi ringkas manuskrip, kutipan awal, kutipan akhir, sumber acuan, dan catatan lain, namun tidak semua item-item yang tercantum dikemukakan, beberapa item yang tidak dideskripsikan jika tidak didapatkan data tersebut dalam manuskrip.

\section{TEMUAN DAN PEMBAHASAN}

Bangsa yang besar adalah bangsa yang tumbuh dari perjalanan sejarah yang panjang dan cemerlang di masa lampau dan mampu melestarikan nilai-nilai budaya dalam menciptakan kesejateraannya pada masa yang akan datang (Mulia, 1998) Nilai-nilai budaya masa lampau terwarisi antara lain melalui naskah-naskah yang ditulis oleh tokoh-tokoh adat atau agama pada masanya. Naskah merupakan salah satu warisan budaya bangsa diantara berbagai artefak lainnya, yang kandungan isinya mencerminkan berbagai pemikiran, pengetahuan, kepercayaan adat istiadat, serta perilaku masyarakat masa lalu (Bafhadal, 2005: 37).

Keberadaan naskah kuno keagamaan, khususnya Islam terkait dengan proses islamisasi di Nusantara, para ulama produktif banyak terlibat di dalamnya. Mereka menulis dalam upaya transmisi keilmuan Islam baik antara ulama Melayu-Nusantara dengan para ulama Timur Tengah, maupun antara ulama Indonesia dengan muridmuridnya diberbagai wilayah di tanah air. Naskah-naskah tersebut ditulis dalam bahasa Arab dan bahasa daerah. Kemudian naskahnaskah tersebut dalam perkembangan tradisi tulis Nusantara menimbulkan pula tradisi penyalinan oleh muridmurid untuk kepentingan belajar, dan oleh tukang-tukang salin untuk kepentingan warga masyarakat secara luas, yang dapat mendatangkan keuntungan (Bafadhal, 2005: 208). Begitupun halnya dengan Negeri Buton terdapat fase-fase dalam penulisan dan penyalinan naskah, fase tersebut dapat dipotret dari masa ke masa. Titik awal dimulainya penulisan, pengkajian, dan pemeliharaan pernaskahan di Wolio-Buton dimulai dari beberapa dekade yang berhubungan langsung dengan sturuktur pemerintahan raja dan sultan dari masa kemasa yaitu:

\section{Fase Raja Wolio V}

Pada masa pemerintahan Raja Wolio V Islam telah masuk ke Buton 
melalui jalur pergadangan antara Maluku dengan Kawasan Barat Nusantara dan Wolio merupakan jalur pelayaran dan perdagangan, pada masa itu penyebaran Islam di negeri Buton telah dimulai, khususnya pada masyarakat pesisir (Batauga dan Kamaru) namun tidak secara terang-terangan, tetapi setelah Raja Wolio V yang bernama Raja MulaE menyatakan diri memeluk agama Islam pada tahun $1527 \mathrm{M}$ maka berkembanglah Islam di lingkungan kerajaan sehingga beliau di berikan gelar Umar Idam.

\section{Fase Raja Wolio VI}

Setelah masa pemerintahan Raja MulaE berakhir dan digantikan oleh Raja Lakilamponto/Haluoleo sebagai Raja Wolio VI, setelah diangkat menjadi raja Wolio VI kemudian menyatakan diri masuk Islam, maka mulailah penyebaran dan perkembangan agama Islam di seluruh wilayah negeri Wolio, dengan dukungan seorang muballig yang bernama Syeh Abdul Wahid yang datang dari Johor pada tahun 948 H/1538 M. Muballig inilah yang membawa Alquran (Wa Kuntere) yang ditulis tangan ke negeri Wolio sebagai pedoman bagi pemeluk agama Islam.

Pada masa pemerintahan Lakilaponto tidak terbatas pada pengembangan Islam saja, namun struktur dan sistem pemerintahan Wolio diubah ke corak Islam, seperti kerajaan menjadi kesultanan, bahkan nama Wolio digantikan menjadi Buton yang berasal dari bahasa arab bantun (perut), karena dipercaya bahwa Buton adalah salah satu pusat bumi. Maka Kesultanan yang dipimpin oleh Lakilaponto adalah
Kesultanan I Buton dengan gelar Sultan Qaimoeddin Khalifatulhamzi dan setelah wafatnya digelar Murhum.

\section{Fase Sultan Buton IV}

Pada masa pemerintahan Sultan Buton IV La Elangi yang bergelar Sultan Dayanu Ihsanuddin, perkembangan agama Islam lebih pesat. Pendidikan pesantren pun mulai diterapkan (zawiah). Lembaga ini membentuk kelompok-kelompok pengajian yang diselenggarakan dalam istana dan rumah-rumah penduduk dengan mengkaji Alquran, Hadis, Fikih, Tasawuf, dan Bahasa Arab. Dalam mengembangkan pendidikan tersebut, ia dibantu oleh muballig yaitu Firus Muhammad dari Arab, Abdullah bin Sulaiman dari Pasai, dan Seorang Putra Kraton Buton (H. Muhammad Ismail). Pada masa pemerintahan Sultan Dayanu Ihsanuddin, diterapkanlah Undang-undang Pemerintahan yang berdasarkan Agama Islam yang disebut Martabat Tujuh. Karya agung ini telah diterjemahkan oleh La Muchir pada tahun 1994 Martabat Tujuah I, 1995 Martabat Tujuh II,1996 Martabat Tujuh III, 1997 Martabat Tujuh IV, dan yang terkahir pada tahun 2003 tentang Sara Pataanguna.

Undang-undang ini juga bersumber dari ajaran Tasawuf bersifat Wujudiyah yang mirip dengan ajaran Hamzah Fansuri dan muridnya Syamsuddin AlSumaterani dari Aceh. Selain itu, diterapkannya pula Undang-undang Pelaksanaan Sosialisasi Masyarakat yang disebut Istiadatul Azali. 


\section{FAse Sultan Buton XXVI}

Pada masa pemerintahan Sultan La Jampi Muhammad Qaimuddin (Sultan Buton XXVI), dibangun sebuah perpustakaan kesultanan untuk menghimpun bukubuku (manuskrip) agama untuk memudahkan para pengkaji ilmu agama Islam sekaligus memomotivasi para pengkaji dan masyarakat untuk menulis dan lebih mendalami ajaran agama Islam.

\section{Fase Sultan Buton XXIX}

Pada masa pemerintahan Sultan Muhammad Aidrus Qaimoeddin (Sultan Buton XXIX) ditetapkan aksara Hijaiah sebagai aksara resmi kesultanan dan semua pejabat kesultanan dan penduduk kraton diwajibkan menguasai Bahasa Arab dan bahasa Wolio. Dekade inilah (1824-1851) yang banyak melahirkan karya manuskrip baik ditulis oleh penulisnya maupun disalin ulang, dan tercatat dalam Katalog Naskah Buton Sultan Muhammad Aidrus Qaimuddin cukup produktif dalam menulis manuskrip yang bertemakan tasawuf dan ajaran Islam. Sumbangsih Sultan Muhammad Aidrus Qaimoeddin pada bidang kesenian dan pendidikan. Pertama, bidang kesenian, Sultan Aidrus menciptakan kabanti atau syair yang bernafaskan Islam dalam bahasa Wolio dan Arab seperti Bula Malino, Jauhari Manikam, Raudatu, Akhan, dan Takhainul Awladi. Kedua dalam bidang pendidikan, Sultan Aidrus medatangkan pengajar Islam dari luar negeri untuk mengajar di lingkungan istana dan masyarakat negeri Buton, serta masyarakat Buton dianjurkan memperdalam ilmu agamanya di luar negeri seperti yang dilakukan Abdul Ganiu yang studi ke Mekah. Setelah tiba di Buton, ia banyak mengajarkan tentang Islam dan melahirkan karya-karya yang bernafaskan Islam diantaranya Anjonga Yodaa Malusa (Pakaian yang Tidak Luntur), Padamarana Yunca, Jaohara Insanu, Zam-zam Ma'rifat, Kanturuna Mohelana (Lampu Orang yang Berlayar), dan Jaohara Ma'nikam Molabina.

\section{Fase Sultan Falihi 1937-1960}

Pada masa pemerintahan Sultan Falihi berbagai jenis arsip dan manuskrip kerajaan yang terhimpun dan dipelihara oleh Mulku (asisten pribadi Sultan Falihi). Kesenangan Mulku adalah menulis yang diwariskan dari buyutnya yang bernama Ma Zahari (pejabat kerajaan/s ekretaris), karena kesenangannya itulah mendapat warisan untuk memelihara berbagai jenis manuskrip kerajaan (Ikram, 2001).

Gambaran pernaskahan dari beberapa dekade di atas tidak dapat dipungkiri bahwa proses kesadaran masyarakat Buton terhadap manuskrip sangatlah besar, penyalinan manuskrip di negeri Buton masih berlangsung sampai sekarang (Harisun, wawancara 2014). Disamping itu sebagai bukti yang paling otentik manuskripmanuskrip masih banyak yang tersebar dan yang disimpan secara perorangan dan belum bisa teridentifikasi secara maksimal dan menyeluruh. Ini dikarenakan bahwa sebagian masyarakat masih mensakralkan manuskrip tersebut dan menganggap sebagai pusaka yang tidak bisa diakses oleh pihak 
luar dan ada ketakutan "penyalahgunaan" manuskrip, seperti manuskrip-manuskrip tasawuf, tarekat, ilmu kekebalan, ilmu kebatinan, dan beberapa doa-doa. Meskipun demikian diantara beberapa manuskrip di Buton bisa diakses melalui pemilik manuskrip yang "terbuka" terhadap peneliti atau yang berkepentingan terhadap manuskrip.

Pemegang atau pewaris manuskrip yang ditemui berasal dari kaomu dan walaka (golongan yang memegang adat dan pengawas pemerintahan kesultanan atau bangsawan). Sedangkan golongan papara (rakyat biasa) sampai sekarang belum teridentifikasi memiliki manuskrip.

Penelitian manuskrip di Buton telah banyak dilakukan baik dari kalangan lembaga pernaskahan, akademisi dan birokrasi dalam maupun luar negeri. Dintaranya Universitas Indonesia (UI), Universitas Hasanuddin (UNHAS), Balai Bahasa, Manassa (Masyarakat Pernaskahan Nusantara), dan Pusat Litbang Lektur Keagamaan. Sedangkan lembaga luar negeri yaitu Malaysia, Belanda, dan Brunai Darussalam. Pada masa peristiwa G/30/S/PKI tahun 1965, negeri Buton mengalami "keterpurukan" di bidang pernaskahan kerena beberapa naskah-naskah yang dikumpul pihak keamanan kemudian dimusnahkan atau dibakar karena dianggap sebagai sumber belajar PKI sehingga diantara beberapa naskah asli tidak ditemukan lagi sekarang ini (Anshari, wawancara 2014).

\section{Peran Pemerintah dalam Bidang Pernaskahan}

Pemerintah Daerah Kota BauBau berperan aktif dalam memlihara dan melestarikan warisan kebudayaan yang dimilikinya. Pertama dibuktikan dengan pemeliharaan dan penyimpanan manuskrip dan benda-benda artefak di museum Kota Bau-Bau. Kedua Pemda kota Bau-Bau memberikan perhatian khusus pada pemilik manuskrip atau kolektor manuskrip, yang diangkat sebagai tenaga luar biasa pada Dinas Pariwisata untuk menjadi informan. Ketiga Dinas Pariwisata Kota Bau-Bau pada tahun 2008 berinisiatif memulangkan beberapa arsip kerajaan Buton dari negeri Kincir Angin Belanda beserta dengan 1.600 microfilm manuskrip Buton. Keempat Pemda Kota BauBau menerbitkan beberapa kajian manuskrip klasik keagamaan misalnya manuskrip Sara Pataanguna dan Martabat Tujuh yang ditulis oleh La Muchir.

\section{Warisan Manuskrip yang Terselamatkan}

Sejumlah manuskrip yang terselamatkan sebagai benda pusaka yang diwariskan secara turun temurun. Manuskrip keagamaan yang ada di tangan masyarakat Buton yang telah teridentifikasi, sebanyak 359 manuskrip dan masih banyak yang tersebar di tangan masyarakat yang dikoleksi secara individu. Dan hasil penelusuran manuskrip yang dilakukan pada penelitian ini pada tiga kecamatan yaitu kecamatan Murhum, Wolio, dan Kokalu-kuna di Bau-Bau. Ketiga kecamatan tersebut masih berpusar dalam lingkup Keraton Kesultanan Buton. 
Khusus di Kecamatan Murhum kelurahan Wameo terdapat satu orang pengoleksi manuskrip yang bernama La Ode Hafilu yang mengoleksi manuskrip sebanyak 4 (empat) buah yang bertemakan tasawuf dan khutbah. Di kelurahan Wajo, terdapat 2 (dua) orang pengoleksi manuskrip yaitu La Ode Abd. Rahman dan Moersidi. La Ode Abd. Rahman mengoleksi 8 (delapan) manuskrip yang bertemakan khutbah, tasawuf, dan ilmu kebatinan. Sedangkan Moersidi mengoleksi 1 (satu) buah manuskrip tentang Silasilah Raja dan Sultan Buton. Di kelurahan Melai terdapat satu orang pengoleksi manuskrip yang bernama Hazirun Kuddus, mengoleksi sebanyak 3 (tiga) manuskrip. Koleksi manuskrip yang terbanyak adalah Almujazi Mulku yang tinggal di kelurahan Baadia, mengoleksi manuskrip \pm 300 merupakan manuskrip dan Arsip Kerajaan dan Kesultanan, Tasawuf, Ilmu Agama Islam, Doa-Doa, Hadis, Fiqhi, Tauhid. Serta la Umbu yang mengoleksi manuskrip sebanyak 10 buah yang bertema Fikih, Hadis, Pelajaran Raudatul Atfal, Silsilah, Syarf al-Anam, dan Doa-doa.

Di kelurahan Lanto, terdapat dua orang pengoleksi manuskrip yaitu M. Said Efu dan Sahabuddin yang mengoleksi kitab Syarf alAnam dan Tasawuf. La Muchir yang tinggal di Kecamatan Tarafu mengoleksi 5 manuskrip tentang Khutbah, Doa-doa, dan Insan Kamil. Di kecamatan Wolio terdapat tiga pengoleksi manuskrip yang tersebar di empat kelurahan Batulo, Toba, dan Wangkanapi. Pengoleksi manuskrip tersebur yaitu: La Ode Anshari yang mengoleksi 6 (enam) buah manuskrip, La Ode Syarifuddin yang mengoleksi 17 manuskrip Tasawuf, Khotbah, Fiqhi, Doa-doa, dan Tauhid; serta La Umbu yang mengoleksi Alquran Wakuntere. Di Kecamatan Kokalu-kuna terdapat satu orang pengoleksi manuskrip yaitu La Ode Malim bertempat tinggal di kelurahan Kadolomoko yang mengoleksi dua buah Kabanti.

Gambaran pemetaan persebaran manuskrip di atas merupakan gabungan dari inventarsisasi manuskrip yang dilakukan oleh Tim dari Balai Litbang Agama Makassar, Tim Manassa tahun 2001, dan Tim dari Pusat Litbang Lektur Keagamaan tahun 2008. Sedangkan dari hasil penelusuran manuskrip yang ditemukan dalam penelitian ini, masih lestari dan terawat oleh ahli waris diantaranya:

\section{Kitab Maulud Syarf al-Anam}

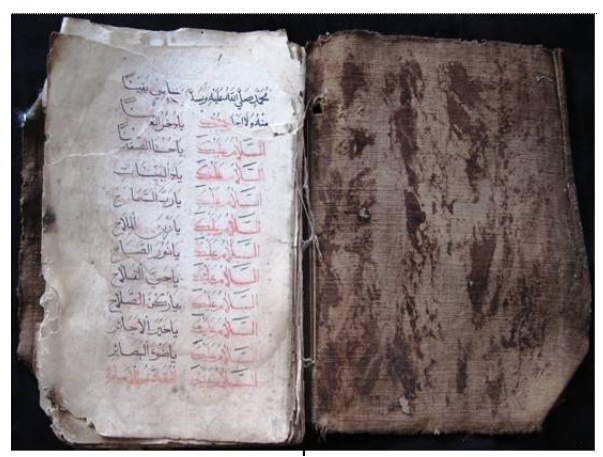

Manuskrip ini berjudul Kitab Maulud Syarf al-Anam yang ditulis dalam bentuk prosa. Kitab Maulud Syarf al-Anam ditulis dalam Bahasa Arab dan menggunkan aksara Hijaiah secara keseluruhan berjumlah 82 halaman dan berjumlah 5 (lima) kuras serta terdapat 1 (satu) halaman kosong. Dalam penulisan menggunakan garis panduan dan 
tidak terdapat nomor halaman, kondisi manuskrip pada pinggirannya lapuk, serta 4 (empat) halaman awal lapuk dan robek namun masih bisa terbaca. Manuskrip ukuran 20.5 x $17 \mathrm{~cm}$ ini bersampul kain bida'(tenunan khas Walio), ukuran teks $16 \times 7 \mathrm{~cm}$, jumlah baris dalam 1 (satu) halaman ratarata 12 baris perhalaman, teks ditulis dengan menggunakan tinta merah dan hitam. Bahan manuskrip ini dari kertas Eropa dengan cap kertas propatria (Churchill, 1935) berwarna kekuningan. Dari watermarks kertas yang digunakan diperkirakan manuskrip ini ditulis pada tahun 1600-an. Manuskrip tersebut dibawa dari Persia menurut pemiliknya. Terdapat 3 (tiga) koleksi manuskrip yang sama yang ditemukan oleh tim peneliti.

Isi manuskrip terdapat tiga bahagian, yang pertama mengenai puji-pujian kepada Nabi Muhammad saw., sebagai nabi yang paling sempurna dan mulia, dan ditutup dengan doa-doa. Bahagian kedua menguraikan tentang salat nisfu Sya'ban terdapat tiga pasal di dalamnya. Pada bagian ketiga terdapat beberapa doa yaitu salawat dan puji-pujian kepada Nabi Muhammad saw., doa meminta ampunan kepada Tuhan, doa meminta berkah, dan doa meminta masuk surga. Koleksi manuskrip ini milik La Umbu, tinggal Kelurahan Wangkanapi Kecamanatan Wolio Kota Bau-Bau.
Yāsin Talqīin

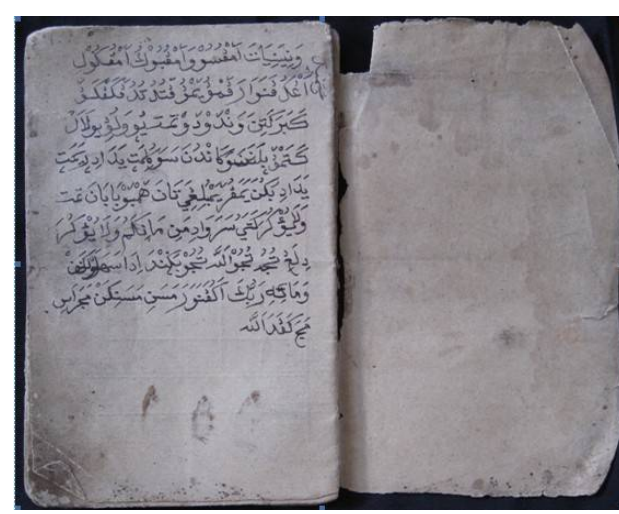

Manuskrip ini tidak ada judulnya. Judul diberikan oleh pendeskripsi yaitu Yāsin Talqīn. Ukuran manuskrip 18x10.8 cm, tebal manuskrip 56 halaman, dengan ukuran teks perhalamannya $7 \times 12 \mathrm{~cm}$, serta 9 (sembilan) baris setiap halaman, dan terdapat 4 (empat) halaman kosong. Manuskrip ini lengkap, terdapat nomor halaman, teks ditulis dalam Bahasa Arab dan sebagai pengantar teks menggunakan Bahasa Wolio dan memakai garis panduan. Bahan manuskrip dari kertas eropa ditulis dengan tinta hitam dan merah. Tinta merah sebagai penanda penting seperti penggalan ayat, penanda awal teks, dan cacatan penting. Manuskrip tersebut dijilid dengan kertas Eropa yang dijahit dengan benang, jumlah kurasnya 3 (tiga) buah. Bentuk tulisan berupa prosa dengan Aksara Hijaiah dan Serang, yang berbahasa Arab dan Wolio.

Isi Manuskrip, terdiri atas tiga bagian. Pada halaman awal merupakan pendahuluan atau panduan tata cara membaca manuskrip ini. Kedua berisi Surah Yāsin ayat 1-83, dan pada bagian ketiga berisi talqin untuk laki-laki dan perempuan. Koleksi manuskrip 
ini adalah milik La Umbu yang beralamat di Kelurahan Wangkanapi Kecamatan Wolio Kota Bau-Bau.

\section{Doa dan Nyayian}

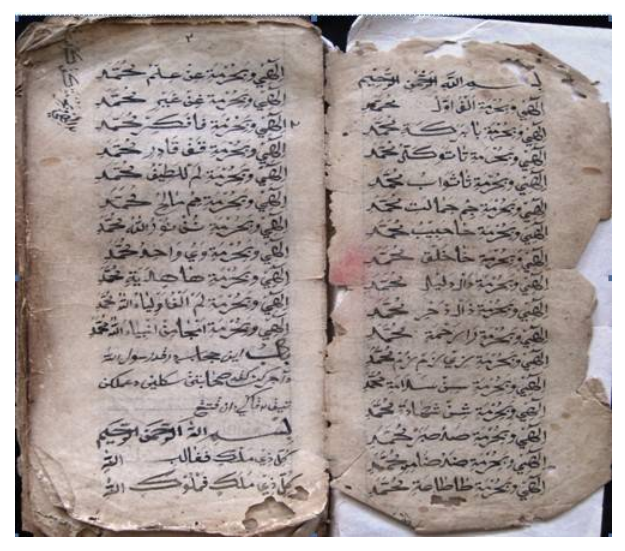

Manuskrip ini tidak ada judulnya. Doa dan nyanyian diberikan oleh pemilik manuskrip. Ukuran manuskrip 29x11 cm, dengan ukuran teks $22.5 \times 7 \mathrm{~cm}$, yang ditulis sebanyak 17 baris perhalaman, dengan ketebalan halaman sebanyak 68 halaman dan jumlah kuras 4 (empat) buah . Bahan manuskrip dari kertas Eropa, ditulis dengan menggunakan tinta warna hitan dan ungu. Di dalam lembaran manuskrip terdapat empat lembaran yang tintanya meleleh. Halaman akhir tidak te ratur (acak). Pada naskah terdapat penomoran halaman mulai dari 1-49 selanjutnya tidak ada penomoran halaman pada lembaran manuskrip. Aksara yang digunakan dalam penulisan adalah Hijaiah dan Lontara, dengan menggunakan Bahasa Arab dan Wolio. Tulisan berbentuk prosa.

Isi manuskrip merupakan doa dan nyanyian. Menurut pemilik, manuskrip ini digunakan untuk mengajar anak-anak (umur tingkatan Raudatul Atfal atauTaman Kanak- kanak) di Keraton Buton. Manuskrp ini bersisi doa, nyanyian, dan pujipujian terhadap Rasulullah saw., belajar menghitung dalam bahasa Arab, nama-nama hari, nama-nama bulan Hijriyah dan Miladiyah, dan doa-doa singkat. Koleksi manuskrip ini milik La Umbu, yang beralamat di Kelurahan Wangkanapi Kecamatan Wolio Kota Bau-Bau.

\section{Khutb ah Jumat}

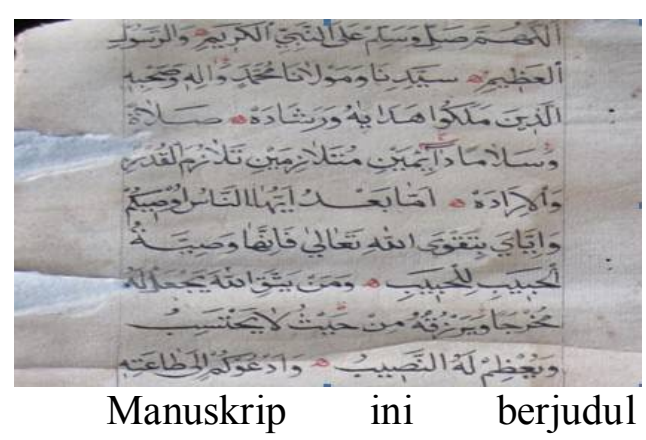

Khutbah Jumat sebanyak dua halaman, dengan panjang 140x16 cm dalam bentuk gulungan. Jenis tulisan Aksara Hijaiah dan berbahasa Arab, menggunakan tinta cina berwarna hitam dan merah. Bahan yang digunakan kertas eropa watermarks propatria, secara fisik manuskrip bagian pinggir manuskrip ini telah rusak dan telah diperbaiki atau dilaminating dengan menggunakan kertas Jepang pada saat kunjungan tim dari Malasysia (Dr. Abd.Razak), secara keseluruhan manuskrip ini masih dapat dibaca. Penulisannya dalam bentuk prosa.

Isi manuskrip yaitu nasehat berupa pesan mengenai kehidupan di dunia dan akhirat kelak, serta mengingatkan umat manusia akan kematian disertai dengan kutipankutipan ayat yang memperkuatnya. Manuskrip ini adalah koleksi La Ode Abdul Muzakkir bin La ode Muhiru, 
tinggal di Jl. Dr. Wahidin No. 6 Kelurahan Tarafu Kecamatan Murhum Kota Bau-Bau.

\section{Silsilah Raja Wolio-Buton}

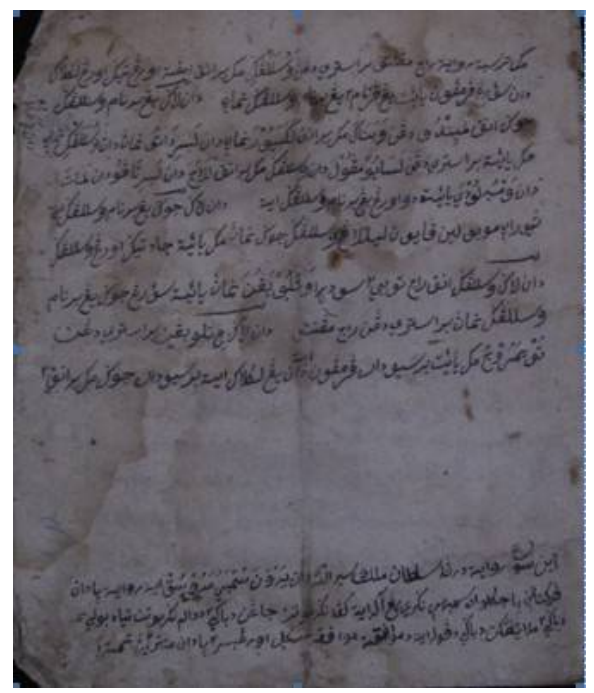

Manuskrip ini tidak ada judulnya. Silsilah sebagai judul manuskrip ini diberikan oleh pemiliknya. Tebalnya 17 halaman dan terdapat 2 halaman kosong, dengan panjang $21 \times 18 \mathrm{~cm}$ dalam bentuk jilidan. Sampul jilid dari kertas Eropa. Tulisan menggunakan aksara Hijaiah dan berbahasa Arab dan Melayu, dengan menggunakan tinta cina berwarna hitam dan merah. Jumlah baris pada halaman pertama sebanyak 12 halaman, penomoran halaman dilakukan kemudian oleh pemilik manuskrip. Bahan yang digunakan adalah kertas eropa, secara fisik manuskrip ini masih utuh dan dapat terbaca dengan jelas.

Isi manuskrip adalah silsilah raja dan sultan di negeri WolioButon. Manuskrip ini merupakan koleksi Moersidi, tinggal di Jl. Labalawo Kel. Wajo Kecamatan Murhum Bau-Bau Sulawesi Tenggara.

\section{Hadis Arbain}

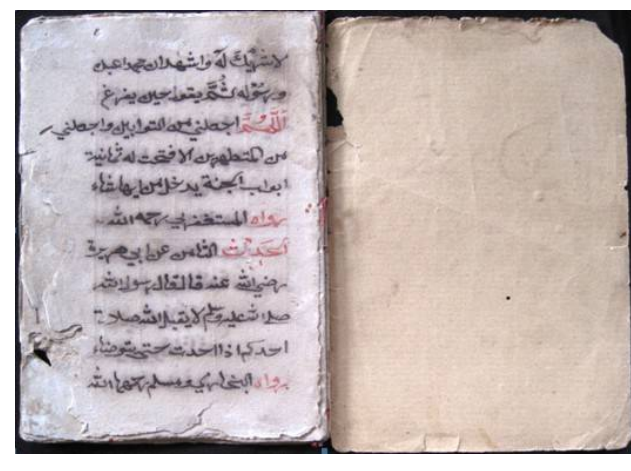

Manuskrip ini tidak ada judulnya. Kitab Hadis 40 sebagai judul luar manuskrip ini, diberikan oleh pemiliknya (La Umbu), yang ditulis oleh $\mathrm{H}$. La Pada, Jilid sampul manuskrip yang digunakan adalah kertas Eropa yang dijahit dengan benang. Ukuran manuskrip $20,2 \times 16,5 \mathrm{~cm}$ dengan ketebalan manuskrip 36 halaman, dan tidak terdapat halaman kosong.

Bahan yang digunakan kertas Eropa, ditulis dengan menggunakan tinta cinta yang berwarna hitam dan merah. Dalam penulisan memakai garis panduan. Jumlah kuras manuskrip tersebut sebanyak 2 kuras dan ukuran teks $7 \times 13.5 \mathrm{~cm}$. Setiap halaman manuskrip terdapat 11 baris teks bagian depan dan pinggiran manuskrip rusak namun masih dapat terbaca secara keseluruhan. Terdapat penomoran halaman pada saat penulisan serta terdapat pada bagian bawah sisi kiri satu kata (awal teks) sebagai penanda pada halaman berikutnya.

Isi manuskrip merupakan kumpulan hadis yang diriwayatkan oleh Bukhari dan Muslim sebanyak 40 hadis. Koleksi manuskrip ini milik La Umbu, tinggal Kelurahan Wangkanapi Kecamanatan Wolio Kota Bau-Bau. 


\section{Fikhi}

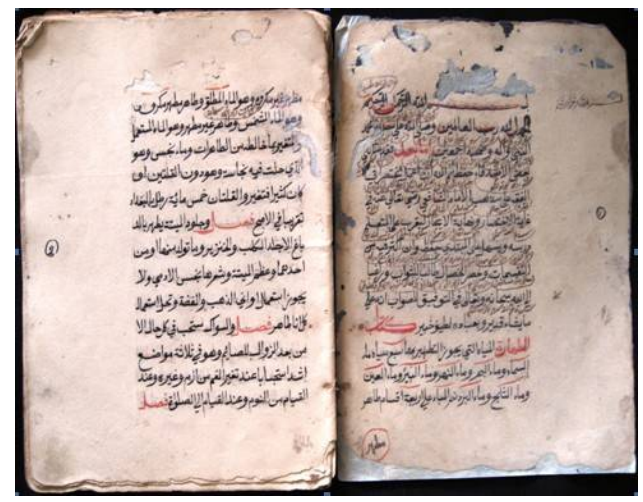

Judul manuskrip ini Fikih. Secara keseluruhan berjumlah 84 halaman, sebanyak 4 (empat) kuras serta terdapat 5 (lima) halaman kosong. Penomoran halaman diberikan kemudian oleh pewaris manuskrip. Terdapat tanda setiap akhir penulisan teks pada tiap lembar halaman di bagian sisi kiri bawah sebagai tanda penulisan pada lembar berikutnya. Kondisi manuskrip utuh secara keseluruhan dan bisa terbaca. Manuskrip berukuran $20.2 \times 16,5 \mathrm{~cm}$ dengan ukuran teks $14 \times 9 \mathrm{~cm}, 13$ baris tiap halaman. Tidak terdapat kolofon dalam manuskrip namun diperkirakan manuskrip ini di tulis sekitar tahun 1667 M. melihat dari bahan yang digunakan yaitu kertas Eropa dengan cap kertas propatria berwarna kekuningan. Teks ditulis dengan menggunakan tinta warna hitam dan merah.

Isi manuskrip merupakan pendahuluan yang menyatakan "Saya diminta dari beliau untuk meringkas fiqhi sesuai dengan mazhab syafii seringkas-ringkasnya untuk medekatkan kepada orang yang ingin mempelajarinya". Manuskrip ini terdiri dari beberapa bab yaitu Tahārah yang terdiri 10 pasal, Salat 6 pasal, Puasa 1 pasal, Haji 2 pasal, Buyu' (jual-beli) 26 pasal, faraid 2 pasal, nikah 15 pasal, Jinayat (pidana) 3 pasal, hudud (ketetapan) 7 pasal, jihad 3 pasal, binatang buruan 3 pasal, perlombaan dan pemanahan, sumpah dan nazar, al-Aqdiya wa al-Syahadah 3 pasal, serta Akikah 3 pasal. Koleksi manuskrip ini milik La Umbu, tinggal Kelurahan Wangkanapi Kecamanatan Wolio Kota Bau-Bau.

\section{PENUTUP}

Sejarah permanuskripan di Buton tidak terlepas ketika datangnya agama Islam di Buton pada masa pemerintahan Raja Wolio $\mathrm{V}$ bernama Raja MulaE yang menyatakan diri menganut agama Islam pada tahun $1527 \mathrm{M}$. Kemudian dilanjutkan oleh Raja Wolio VI yang aktif mengembangkan Islam di Kesultanan Buton yang dibantu oleh yang bernama Syeh Abdul Wahid yang datang dari Johor pada tahun 948 H/1538 M. Muballig inilah yang membawa Alquran (Wa Kuntere) yang ditulis tangan ke negeri Wolio sebagai pedoman bagi pemeluk agama Islam. Usaha ini dilanjutkan secara berturut-turut oleh pihak pemerintahan Kesultanan Buton yaitu Sultan Buton IV La Elangi yang bergelar Sultan Dayanu Ihsanuddin diterapkan Undangundang Pemerintahan yang berdasarkan Agama Islam yang disebut Martabat Tujuh. Pada masa Sultan La Jampi Muhammad Qaimuddin (Sultan Buton XXVI) membangun sebuah perpustakaan kesultanan untuk menghimpun bukubuku dan manuskrip untuk memudahkan para pengkaji ilmu 
agama. Pada masa pemerintahan Sultan Muhammad Aidrus Qaimoeddin (Sultan Buton XXIX) 1824-1851 banyak melahirkan manuskrip karena pada zaman itu aksara Hijaiah dan Bahasa Arab sebagai bahasa resmi kesultanan dan semua pejabat kesultanan dan penduduk keraton diwajibkan menguasai Bahasa Arab dan Bahasa Wolio. Kemudian dilanjutkan pada masa Sultan Falihi 1937-1960 yang banyak menyalin manuskrip dan sebagai Sekretaris Kesultanan Buton.

Pemilik manuskrip keagamaan yang ditemukan di masyarakat Buton umumnya merupakan keturunan Sultan Buton atau keturunan dari perangkat kesultanan dan perangkat struktur lembaga keagamaan Kesultanan Buton. Sebagian besar pemilik mensakralkan manuskripnya dan masih berpegang teguh bahwa manuskrip adalah sebagai benda pusaka. Manuskrip yang ditemukan berisi tentang Tasawuf, Khutbah, Ilmu Kebatinan, Silsilah Raja dan Sultan Buton, Arsip Kerajaan dan Kesultanan, Ilmu Agama Islam, Doadoa, Hadis, Tauhid, Fikih, Hadis, Silsilah, Syarf al-Anam, Insan Kamil, Tauhid, Alquran, serta Kabanti.

\section{DAFTAR PUSTAKA}

Bafadhal, Fadhal AR dan Asep Saefullah (ed). 2005. Naskah Klasik Keagamaan Nusantara I Cerminan Budaya Bangsa. Jakarta: Puslitbang Lektur Keagamaan Badan Litbang Agama dan Dikalt Keagamaan.

Behred, T.E (penyunting). 1998. Katalog Induk Naskah-Naskah
Nusantara, jilid 4. Jakarta: Yayasan Obor Indonesia.

Ekadjati, Edi S dkk. 2000. Direktori Edisi Naskah Nusantara. Jakarta: Yayasan Obor Indonesia.

Churchill, W.A. 1935. Watermarks in Paper: in Holland, France, England, etc. in XVII and XVIII Centuries and Their Interconnection. Amsterdam: Menno Hertzberger.

Ikhsanuddin, Dayanu diterjemahkan oleh La Muchir. 1994. Martabat Tujuh Sumber (Hukum, Azas, Dasar, Teladan Adab dan Tarekat Adat Istiadat Butuni I). Tarafu-Buton (tidak diterbitkan).

1995. Martabat Tujuh (Sumber Hukum, Azas, Dasar, Teladan Adab dan Tarekat Adat Istiadat Butuni II). Tarafu-Buton (tidak diterbitkan). 1996. Martabat Tujuh ( Sumber Hukum, Azas, Dasar, Teladan Adab dan Tarekat Adat Istiadat Butuni III). Tarafu-Buton (tidak diterbitkan).

1997. Martabat Tujuh (Sumber Hukum, Azas, Dasar, Teladan Adab dan Tarekat Adat Istiadat Butuni IV). Tarafu-Buton (tidak diterbitkan). 2003. Sara Pataanguna (Memanusiakan Manusia Menjadi Manusia Khalifatullah di Bumi Kesultanan Butuni). Bau-Bau: Pemda Bau-Bau. 
Ikram, Achdiati dkk (penyunting). 2001. Katalog Naskah Buton Koleksi Abdul Mulku Zahari. Jakarta: Manassa, The Toyota Foundation, dan Yayasan Obor Indonesia.

Mulia Musda dkk (ed). 1998. Katalog Naskah Kuno yang Bernafaskan Islam di Indonesia I. Jakarta: Badan Litbang Agama Departemen Agama RI.

1999. Katalog Naskah Kuno yang Bernafaskan Islam di Indonesia II. Jakarta: Badan Litbang Agama Departemen Agama RI.

Paeni, Mukhlis dkk. 2003. Katalog Induk Naskah-naskah Nusantara Sulawesi Selatan. Jakarta: Arsip Nasional RI kerjasama dengan The Ford Foundation, UNHAS, dan Gajah Mada Universitas Press. 
Jurnal Pusaka, Vol. 5, No.1, 2017 